\title{
Condition of larvae of western rock lobster (Panulirus cygnus) in cyclonic and anticyclonic eddies of the Leeuwin Current off Western Australia
}

\author{
Miao Wang ${ }^{\mathrm{A}, \mathrm{F}}$, Richard O'Rorke ${ }^{\mathrm{B}}$, Anya M. Waite ${ }^{\mathrm{C}}$, Lynnath E. Beckley ${ }^{\mathrm{D}}$, \\ Peter Thompson ${ }^{\mathrm{E}}$ and Andrew G. Jeffs ${ }^{\mathrm{A}}$ \\ A Leigh Marine Laboratory, Institute of Marine Science, University of Auckland, Box 349, \\ Warkworth 0941, New Zealand. \\ ${ }^{B}$ School of Biological Sciences, University of Auckland, Private Bag 92019, Auckland 1142, \\ New Zealand. \\ ${ }^{\mathrm{C}}$ School of Environmental Systems Engineering and the Oceans Institute, University of Western \\ Australia, 35 Stirling Highway, Crawley, WA 6009, Australia.

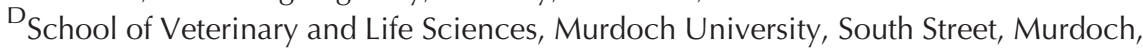 \\ WA 6150, Australia. \\ ${ }^{\mathrm{E}}$ Australian Commonwealth Scientific Industrial and Research Organisation, Hobart, \\ Tas. 7000, Australia. \\ FCorresponding author. Email: miaowfly@gmail.com
}

\begin{abstract}
Changes in the offshore oceanographic processes are suspected to be the cause of a recent dramatic decline in the settlement of post-larvae of the Western Australian spiny lobster (Panulirus cygnus), which has greatly reduced the productivity from the world's second-largest spiny lobster fishery. The present study assessed whether there are differences in the nutritional condition of the larvae of P. cygnus sampled from two pairs of cyclonic eddies (CEs) and anticyclonic eddies (AEs). Morphometric and biochemical analyses were undertaken on the mid-late-stage larvae (VI, VII, VIII) sampled offshore from two pairs of adjacent counter-rotating mesoscale eddies in the Leeuwin Current off Western Australia. The results showed that larvae captured from CEs had greater average total dry mass $(P<0.001)$ than those from AEs. Stage VIII larvae from CEs contained more protein $(P<0.008)(38.5 \% \pm 5.4$ s.e. $)$ and lipid $(P<0.005)$ $(67.2 \% \pm 12.1)$ than did those from AEs. The possible causes for these differences are uncertain but may be related to differences in water temperatures in CEs $v$. AEs influencing the ability of phyllosomas to accumulate nutritional reserves.
\end{abstract}

Additional keywords: eddy, nutritional condition, phyllosoma, spiny lobster.

Received 3 May 2014, accepted 22 December 2014, published online 12 May 2015

\section{Introduction}

The manner in which environmental factors affect the health of spiny lobster larvae (i.e. phyllosomas) is poorly understood. Experiments on cultured phyllosomas have indicated that their prey density and temperature are key determinants for their healthy development (Tong et al. 2000; Liddy et al. 2004). Understanding how environmental factors affect phyllosoma health is crucial, because declining numbers of settling postlarvae has recently been described in the three largest populations of spiny lobsters in the world, causing concern for the major fisheries that they support (Ehrhardt and Fitchett 2010; Linnane et al. 2010; Feng et al. 2011). The most dramatic decline has been observed in the world's second-largest spiny lobster fishery, that is for the Western Australian spiny lobster, Panulirus cygnus (Brown 2011). It has had an annual commercial catch varying between 5899 and $14523 \mathrm{t}$ over the past
30 years, before catch quotas were implemented (de Lestang and Melville-Smith 2006). The variation in the landings of adult lobsters from the fishery has largely been due to natural interannual fluctuations in the settlement of post-larvae, known as pueruli (Caputi et al. 2001). The positive relationship between pueruli settlement on the coast and the subsequent catch of adult lobsters in the commercial fishery has been used for many years as an effective means for managing the fishery (Phillips 1986; Morgan et al. 1982).

Interannual fluctuations in pueruli settlement, as measured with collectors deployed along the Western Australian coastline, have traditionally had a strong positive relationship with the strength of the Leeuwin Current, which flows southward along the coast of Western Australia, and to a large degree determines the oceanic conditions for the developing phyllosomas of the Western Australian spiny lobster (Pearce and Phillips 
1988). However, in recent years, this relationship has broken down, with historically low annual settlement of pueruli being recorded regardless of the strength of the Leeuwin Current (Feng et al. 2011). The cause of the breakdown in this relationship is uncertain but appears to be related to oceanographic processes (Säwström et al. 2014). The phyllosomas of P. cygnus hatch from egg clutches held on adult females living on the continental shelf of Western Australia between December and March. After hatching, the phyllosomas are transported into offshore waters where they develop for $\sim 9-11$ months (Chittleborough and Thomas 1969). Most of this larval period is spent in oceanic waters beyond the continental shelf margin, and can extend to over $1500 \mathrm{~km}$ offshore from the coast of Western Australia (Phillips et al. 1979). Significantly, the phyllosoma period is used to accumulate sufficient nutritional reserves to fuel the subsequent active migration as non-feeding pueruli back into coastal waters where they settle into reefs, which occurs between August to January (Phillips et al. 2006). The nutritional status of pueruli is known to be critical to their successful crossshelf migration (Wilkin and Jeffs 2011; Fitzgibbon et al. 2013). Therefore, oceanic processes that disrupt the accumulation of nutrients by phyllosomas will have a detrimental effect on subsequent onshore settlement.

During the pelagic phase, the waters that the phyllosomas occupy are highly influenced by a fairly narrow $(\sim 100 \mathrm{~km}$ wide) and shallow $(<300-\mathrm{m}$ depth) current, which is the Leeuwin Current. It transports warmer water of tropical origin southward along the shelf break of Western Australia, impinging on the surrounding subtropical surface water, particularly during the winter months when the current is stronger (Church et al. 1989). The offshore distribution of phyllosomas appears to be greatly affected by their entrapment in the series of counter-rotating mesoscale eddies that are established through the interaction of the Leeuwin Current (Griffin et al. 2001), the Leeuwin Undercurrent and topographical eddies (such as shelf topography variations and bottom shear). These features become a dominant oceanographic feature offshore of Western Australia at this time (Rennie et al. 2007). However, the manner in which the formation of eddies affects the nutritional condition and transport of phyllosomas is unknown. Eddies are frequently coupled, with anticyclonic eddies (AEs) comprising a core of warmer water derived from a mixture of water from the Leeuwin Current and shelf, and cyclonic eddies (CEs) with a core of cooler water upwelled from the Leeuwin Undercurrent (Rennie et al. 2007). May is a peak time for the generation of long-lived $\mathrm{CE}$ and $\mathrm{AE}$ pairs in the Leeuwin Current that can persist for 5-18 months (Morrow et al. 2003; Cresswell and Griffin 2004; Feng et al. 2007; Moore et al. 2007). In the region of $28-32^{\circ} \mathrm{S}$ off the coast of Western Australia, almost all eddies have an average radius of $100 \mathrm{~km}$, with little fluctuation from their first formation and typically for up to 8 months, which is a sufficient period to encompass almost the whole larval phase of P. cygnus (Fang and Morrow 2003). Therefore, each eddy is sufficiently large and persistent to create a localised marine environment that is partially isolated from the surrounding subtropical surface waters. Each eddy develops its own distinctive food web, which very frequently includes entrapped phyllosomas of P. cygnus (Strzelecki et al. 2007; Waite et al. 2007a).
Studies of mesoscale eddies formed by the Leeuwin Current have consistently found that, within AEs, there is higher primary productivity that supports a greater biomass of zooplankton, than in CEs (Paterson et al. 2007; Strzelecki et al. 2007; Waite et al. 2007a, 2007b). The marked differences in the physical and biological conditions within an individual eddy could reduce the opportunities of phyllosomas to feed and accumulate sufficient nutrients to facilitate their subsequent migration and recruitment as pueruli into coastal waters.

The aim of the current study is to assess whether there are differences in the nutritional condition of phyllosomas of $P$. cygnus sampled from two pairs of CEs and AEs in the Leeuwin Current, to understand the role of eddy systems in the subsequent survival and settlement of pueruli.

\section{Materials and methods}

\section{Sample collection}

Spiny lobster phyllosomas (Panulirus cygnus) were sampled from the RV Southern Surveyor in the Indian Ocean off Western Australia from 27 August to 1 September 2011 (Fig. 1). The

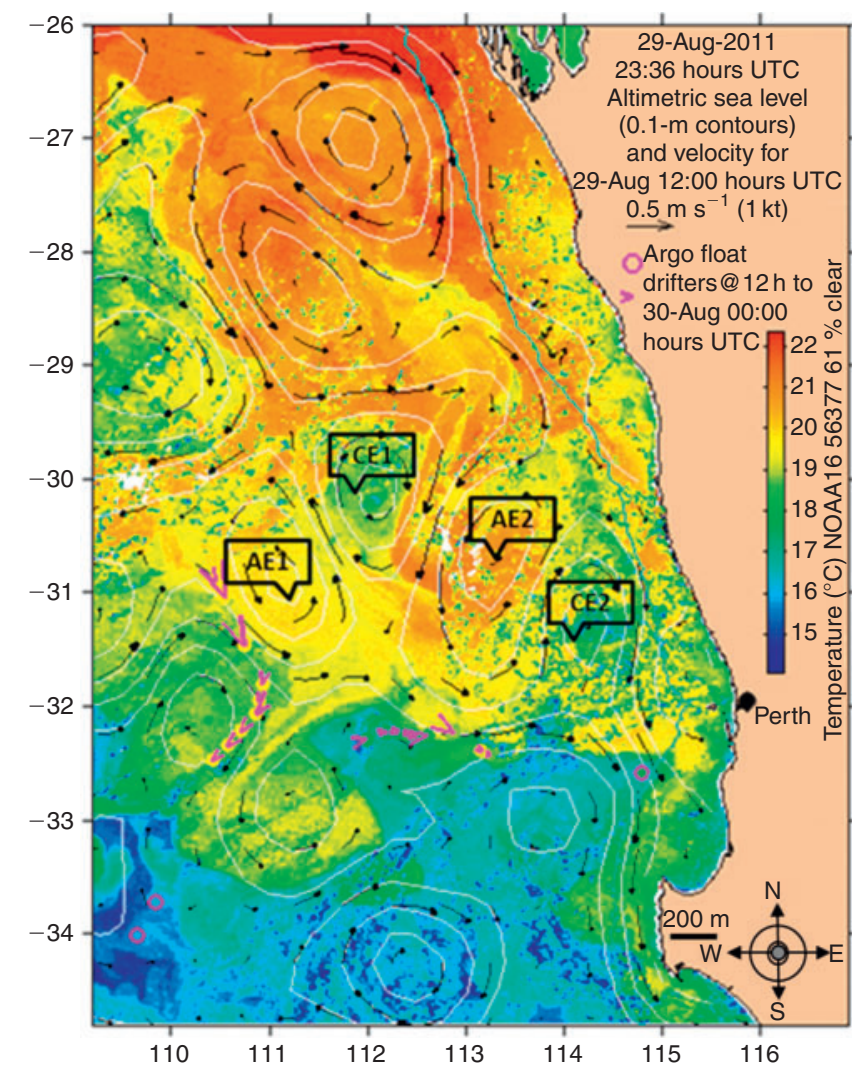

Fig. 1. Position of the four phyllosoma sampling sites off Western Australia against a background of satellite-derived sea surface temperature and sea surface geostrophic current flows for 31 August 2011. AE1, anticyclonic Eddy \#1, sampled on 27 August 2011; AE2, anticyclonic Eddy \#2, sampled on 29 August 2011; CE1, cyclonic Eddy \#1, sampled on 1 September 2011; and CE2, cyclonic Eddy \#2, sampled on 30 August 2011. Satellite data were derived from National Oceanic and Atmospheric Administration (NOAA) and analyses supplied under the auspices of the Australian Integrated Marine Observing System (IMOS). 
sampling sites were two adjacent pairs of counter-rotating eddies in the Leeuwin Current (Table 1). All samples were collected in a consistent manner by deploying a surface net (1-m diameter, 1-mm mesh towed at $0-3-\mathrm{m}$ depth) at night for $\sim 10 \mathrm{~min}$ at less than $3.7 \mathrm{~km} \mathrm{~h}-^{1}$. On recovery of the net, phyllosomas were immediately sorted from the catch, their development stage determined by examination under a dissecting microscope (onboard the vessel) according to the key of Braine et al. (1979), and then frozen on board the vessel at $-80^{\circ} \mathrm{C}$ for later morphometric and biochemical analysis. From the total catch of phyllosomas, 18 individuals collected from each of the four sampled eddies were used for morphometric and biochemical analyses, i.e. six phyllosomas for each of Stages VI, VII and VIII that were randomly selected from the samples taken at each of the four eddies. In total, 72 phyllosomas were analysed.

\section{Morphometric analyses}

Digital images of each phyllosoma held against a reference grid were captured using a camera (Canon DIGITAL IXUS 95 IS, Tokyo, Japan). The body length (from the anterior margin of the cephalic shield between the eyestalks to the posterior tip of the pleon) and cephalic shield width (the widest section of the cephalic shield) of phyllosomas were measured from the images by using Image J software (Image J 1.44 p, Wayne Rasband, National Institutes of Health, Bethesda, MD, USA). All pereiopods were removed from each phyllosoma before weighing the wet mass of the remaining body to ensure consistency among individuals, because during sampling some of the fragile pereiopods were broken off or damaged on some specimens. Phyllosomas were then lyophilised for $24 \mathrm{~h}$ and re-weighed for dry mass, and then used for biochemical analyses.

\section{Biochemical analyses}

The lipid content of each individual lyophilised phyllosoma was determined gravimetrically with a modified (Bligh and Dyer 1959) one-phase methanol-chloroform-water extraction. After lipid extraction, individual phyllosomas were lyophilised again and then homogenised with a micropestle. Half the sample was used for analysis of protein content and the other half for carbohydrate content.

The protein content of each phyllosoma was measured by first digesting the samples for $12 \mathrm{~h}$ in $0.1 \mathrm{~mol} \mathrm{~L}^{-1} \mathrm{NaOH}$ at $50^{\circ} \mathrm{C}$ and then assaying with the bicinchoninic acid (BCA) method with a micro-BCA protein assay kit (Thermo Scientific, Pierce, Rockford, IL, USA) and by using bovine serum albumin as the reference protein.
The dissolved carbohydrate fraction of each phyllosoma was measured with a phenol sulphuric acid reagent method according to DuBois et al. (1956) and was referenced against a D-glucose standard.

Lipid: protein ratio was calculated as the measured mass of lipid $v$. protein for each phyllosoma.

The measured masses of protein, lipid and carbohydrate were converted to energy equivalents using the estimated combustion enthalpy coefficients of $23.9 \mathrm{~kJ} \mathrm{~g}^{-1}$ for protein, $39.5 \mathrm{~kJ} \mathrm{~g}^{-1}$ for lipid and $17.5 \mathrm{~kJ} \mathrm{~g}^{-1}$ for carbohydrate (Gnaiger $1983)$, such that total energy $(\mathrm{kJ})=($ protein mass $\times 23.9)+$ (lipid mass $\times 39.5)+($ carbohydrate mass $\times 17.5)$.

\section{Statistical analyses}

To test whether the stage of phyllosoma development and the location from where it was sampled influenced the mean body length, cephalic shield width, wet and dry body mass, and biochemical composition (i.e. protein, lipid, carbohydrate), a twoway ANOVA were used. Separate two-way ANOVAs were used to compare among phyllosomas from within the two CEs, and from within the two AEs. These analyses indicated a lack of differences in the means of the variables within respective eddy types, so the data were pooled by eddy type to allow for a more rigorous comparison of these data for CEs $v$. AEs. The data analyses made use of the software SigmaPlot for Windows (v. 11.0, Systat Software Inc., Erkrath, Germany). Prior to analyses, the normality of the data was verified with a ShapiroWilk's test, and homogeneity of variances with Levene's test. When data departed from the requirements for ANOVA, a $\log _{10}$ transformation was performed on the data and the transformed data were tested again to confirm compliance with assumptions required for ANOVA. A statistical significance level of $\alpha=0.05$ was employed for all analyses, except where the same data were used in multiple ANOVA analyses, where a Bonferroni correction was applied to adjust the significance level to control for inflated Type II errors (Holm 1979). Where ANOVA results were significant, post hoc comparisons of pairs of means were undertaken using a Holm-Sidak test. All data have been presented as mean \pm standard error.

\section{Results}

In total, 449 phyllosomas from Stages V to IX were caught from the two CEs $(n=94)$ and two AEs $(n=355)$ (Table 1$)$.

\section{Comparison of phyllosomas between similar eddies}

Comparisons for each of the morphometric and biochemical variables (i.e. cephalic shield width, body length, dry mass, wet

Table 1. Total catch of phyllosomas of each larval developmental stage, location of capture with estimated distance from the shore of the four phyllosoma sampling sites, and average water temperature at 40- and 100-m depth recorded from CTD (conductivity, temperature and depth) casts

\begin{tabular}{|c|c|c|c|c|c|c|c|c|c|c|}
\hline \multirow[t]{2}{*}{ Eddy } & \multirow[t]{2}{*}{ Latitude } & \multirow[t]{2}{*}{ Longitude } & \multirow{2}{*}{$\begin{array}{l}\text { Distance from } \\
\text { the shore }(\mathrm{km})\end{array}$} & \multirow{2}{*}{$\begin{array}{l}\text { Average temperature } \\
\text { at } 40 \mathrm{~m}\left({ }^{\circ} \mathrm{C}\right)\end{array}$} & \multirow{2}{*}{$\begin{array}{l}\text { Average temperature } \\
\text { at } 100 \mathrm{~m}\left({ }^{\circ} \mathrm{C}\right)\end{array}$} & \multicolumn{5}{|c|}{ Number of phyllosomas } \\
\hline & & & & & & Stage V & Stage VI & Stage VII & Stage VIII & Stage IX \\
\hline $\mathrm{AE} \# 1$ & -31.14 & 111.38 & 350 & 20.05 & 20.03 & 5 & 69 & 71 & 28 & 1 \\
\hline $\mathrm{AE} \# 2$ & -30.32 & 113.11 & 150 & 21.18 & 20.69 & 0 & 25 & 73 & 83 & 0 \\
\hline CE \#1 & -29.48 & 112.10 & 250 & 19.56 & 19.19 & 0 & 6 & 10 & 17 & 0 \\
\hline $\mathrm{CE} \# 2$ & -31.17 & 114.18 & 100 & 18.36 & 18.13 & 1 & 16 & 23 & 20 & 1 \\
\hline
\end{tabular}


Table 2. Results of two-way ANOVAs applied to compare the effects of stage (VI, VII, VIII) and location (cyclonic eddy (CE) \#1 and \#2) on the morphometric and biochemical parameters of western rock lobster phyllosoma (Panulirus cygnus) sampled from two CEs in the Leeuwin Current off Western Australia

Significant effects are shown in bold

\begin{tabular}{|c|c|c|c|c|c|c|c|c|c|}
\hline Source of variation & $\begin{array}{c}\text { Stage } \\
\text { d.f. }=2 \\
\text { SS }\end{array}$ & $F$-value & \multicolumn{2}{|r|}{$\begin{array}{c}\text { Location } \\
\text { d.f. }=1 \\
\text { SS }\end{array}$} & $F$-value & $P$-value & \multicolumn{2}{|c|}{$\begin{array}{l}\text { Stage } \times \text { Location } \\
\text { d.f. }=2\end{array}$} & $P$-value \\
\hline Wet mass (mg) & 0.253 & 5.761 & 0.008 & 0.011 & 0.507 & 0.482 & 0.031 & 0.702 & 0.503 \\
\hline Dry mass (mg) & 0.132 & 3.658 & 0.038 & 0.000 & 0.025 & 0.874 & 0.013 & 0.359 & 0.701 \\
\hline Width (mm) & 24.034 & 23.301 & $<0.001$ & 0.698 & 1.354 & 0.254 & 0.202 & 0.196 & 0.823 \\
\hline Length (mm) & 0.080 & 23.900 & $<0.001$ & 0.003 & 1.598 & 0.216 & 0.001 & 0.222 & 0.802 \\
\hline Protein (mg) & 0.155 & 4.525 & 0.019 & 0.002 & 0.100 & 0.754 & 0.008 & 0.240 & 0.788 \\
\hline Lipid (mg) & 0.558 & 8.228 & 0.001 & 0.005 & 0.161 & 0.691 & 0.036 & 0.534 & 0.592 \\
\hline Carbohydrate (mg) & 0.070 & 6.075 & 0.006 & 0.003 & 0.466 & 0.500 & 0.008 & 0.695 & 0.507 \\
\hline Lipid: protein & 0.063 & 6.196 & 0.006 & 0.001 & 0.192 & 0.664 & 0.010 & 0.980 & 0.387 \\
\hline Energy $(\mathrm{kJ})$ & 0.401 & 8.324 & 0.001 & 0.004 & 0.167 & 0.686 & 0.020 & 0.408 & 0.668 \\
\hline
\end{tabular}

Table 3. Results of 2-way ANOVAs applied to compare the effects of stage (VI, VII, VIII) and location (anticyclonic eddy (AE) \#1 and \#2) on the morphometric and biochemical parameters of western rock lobster phyllosoma (Panulirus cygnus) sampled from two AEs in the Leeuwin Current off Western Australia

Significant effects are shown in bold

\begin{tabular}{|c|c|c|c|c|c|c|c|c|c|}
\hline \multirow[t]{2}{*}{ Source of variation } & \multirow{2}{*}{$\begin{array}{c}\text { Stage } \\
\text { d.f. }=2 \\
\text { SS }\end{array}$} & \multirow[b]{2}{*}{$F$-value } & \multirow{2}{*}{\multicolumn{2}{|c|}{$\begin{array}{c}\text { Location } \\
\text { d.f. }=1 \\
\text { SS }\end{array}$}} & \multirow[b]{2}{*}{$F$-value } & \multicolumn{4}{|c|}{ Stage $\times$ Location } \\
\hline & & & & & & $P$-value & $\begin{array}{c}\text { d.f. }=2 \\
\text { SS }\end{array}$ & $F$-value & $P$-value \\
\hline Wet mass (mg) & 1703.163 & 7.520 & 0.002 & 35.522 & 0.314 & 0.580 & 80.258 & 0.354 & 0.705 \\
\hline Dry mass (mg) & 33.309 & 3.748 & 0.035 & 21.252 & 4.783 & 0.037 & 0.699 & 0.079 & 0.925 \\
\hline Width (mm) & 15.187 & 22.967 & $<0.001$ & 0.303 & 0.918 & 0.346 & 0.657 & 0.994 & 0.382 \\
\hline Length (mm) & 108.298 & 26.484 & $<0.001$ & 2.421 & 1.184 & 0.285 & 3.194 & 0.781 & 0.467 \\
\hline Protein (mg) & 2.604 & 4.251 & 0.024 & 1.042 & 3.403 & 0.075 & 0.011 & 0.018 & 0.982 \\
\hline Lipid (mg) & 4.952 & 8.364 & 0.001 & 1.138 & 3.843 & 0.059 & 0.019 & 0.032 & 0.969 \\
\hline Carbohydrate (mg) & 0.008 & 0.489 & 0.618 & 0.006 & 0.787 & 0.382 & 0.011 & 0.712 & 0.499 \\
\hline Lipid:protein & 0.140 & 10.542 & $<0.001$ & 0.027 & 4.119 & 0.051 & 0.003 & 0.202 & 0.818 \\
\hline Energy (kJ) & 0.019 & 7.637 & 0.002 & 0.004 & 3.500 & 0.071 & 0.000 & 0.009 & 0.991 \\
\hline
\end{tabular}

mass, protein, lipid, and carbohydrate content) for the three stages of phyllosomas (i.e. Stages VI, VII and VIII) found no significant differences among any of these means between the two CEs (2-way ANOVA, Table 2). This was also the case for the two AEs (2-way ANOVA, Table 3). Consequently, the data were pooled for each type of eddy for subsequent comparison of CEs with AEs.

\section{Phyllosomas from CEs v. AEs: phyllosoma morphometrics}

Comparison of mean phyllosoma cephalic shield width and body length showed overall significant differences by stage, but not for CEs $v$. AEs, or for the interaction term (2-way ANOVA, Table 4).

There was a significant increase in mean cephalic shield width from phyllosoma Stages VI to VII $(0.7 \mathrm{~mm} \pm 0.2,9.6 \% \pm$ 2.9 wider, $P<0.001$ ), from Stages VII to VIII ( $1.0 \mathrm{~mm} \pm 0.3$, $13.0 \% \pm 3.8$ wider, $P<0.001)$, and from Stages VI to VIII $(P<0.001)$, regardless of location of capture. The body length of phyllosomas increased significantly from Stages VI to VII (1.5 mm $\pm 0.4,9.5 \% \pm 2.9$ longer, $P=0.001)$, from Stages VII to VIII $(3.0 \mathrm{~mm} \pm 0.7,17.0 \% \pm 4.1, P<0.001)$, and from Stages VI to VIII $(P<0.001)$, regardless of location of capture. The body length of the analysed phyllosomas ranged from 14.0 to $18.8 \mathrm{~mm}$, from 14.7 to $20.9 \mathrm{~mm}$, and from 17.8 to $26.4 \mathrm{~mm}$ for Stages VI, VII and VIII respectively.

\section{Phyllosomas from CEs v. AEs: phyllosoma mass}

Comparisons of both mean wet and mean dry mass showed significant differences for CEs $v$. AEs, significant increases by stage, but not for the interaction term (2-way ANOVA, Table 4).

The mean wet mass of phyllosomas for CEs was significantly higher than that for AEs $(P=0.002, P=0.024, P=0.002$ for Stages VI, VII, and VIII respectively; Fig. 2). The mean wet mass of phyllosomas from CEs increased significantly from Stages VI to VIII $(P=0.002)$, and from Stages VII to VIII $(P=0.013)$, and in AEs from Stages VI to VIII $(P=0.001)$. Over all four eddies, the wet mass of sampled Stage VII phyllosomas was $18.6 \% \pm 10.2$ greater than that of Stage VI, and wet masses of Stage VIII phyllosomas were $37.4 \% \pm 7.7$ greater than those of Stage VII. 
Table 4. Results of 2-way ANOVAs applied to compare the effects of stage (VI, VII, VIII) and eddy (cyclonic (CE) and anticyclonic (AE) eddy) on the morphometric and biochemical parameters of western rock lobster phyllosoma (Panulirus cygnus) sampled from CEs and AEs in the Leeuwin Current off Western Australia

Significant effects are shown in bold

\begin{tabular}{|c|c|c|c|c|c|c|c|c|c|}
\hline \multirow[t]{2}{*}{ Source of variation } & \multicolumn{2}{|l|}{ Stage } & \multicolumn{3}{|c|}{ Eddy } & \multicolumn{4}{|c|}{ Stage $\times$ Eddy } \\
\hline & $\begin{array}{c}\text { d.f. }=2 \\
\text { SS }\end{array}$ & $F$-value & $P$-value & $\begin{array}{c}\text { d.f. }=1 \\
\text { SS }\end{array}$ & $F$-value & $P$-value & $\begin{array}{c}\text { d.f. }=2 \\
\text { SS }\end{array}$ & $F$-value & $P$-value \\
\hline Wet mass (mg) & 0.487 & 13.873 & $<0.001$ & 0.455 & 25.903 & $<0.001$ & 0.011 & 0.301 & 0.741 \\
\hline Dry mass (mg) & 0.180 & 6.748 & 0.002 & 0.289 & 21.612 & $<0.001$ & 0.017 & 0.638 & 0.532 \\
\hline Width (mm) & 0.366 & 44.372 & $<0.001$ & 0.009 & 2.265 & 0.137 & 0.026 & 3.120 & 0.051 \\
\hline Length (mm) & 0.136 & 49.347 & $<0.001$ & 0.002 & 1.277 & 0.262 & 0.007 & 2.451 & 0.094 \\
\hline Protein $(\mathrm{mg})$ & 0.350 & 14.073 & $<0.001$ & 0.107 & 8.567 & 0.005 & 0.026 & 1.036 & 0.361 \\
\hline Lipid (mg) & 0.863 & 16.554 & $<0.001$ & 0.300 & 11.509 & 0.001 & 0.055 & 1.058 & 0.353 \\
\hline Carbohydrate (mg) & 0.060 & 4.544 & 0.014 & 0.009 & 1.423 & 0.237 & 0.018 & 1.353 & 0.266 \\
\hline Lipid : protein & 0.116 & 14.938 & $<0.001$ & 0.0488 & 12.569 & $<0.001$ & 0.00615 & 0.791 & 0.457 \\
\hline Energy (kJ) & 0.6 & 15.823 & $<0.001$ & 0.201 & 10.592 & 0.002 & 0.0415 & 1.094 & 0.341 \\
\hline
\end{tabular}
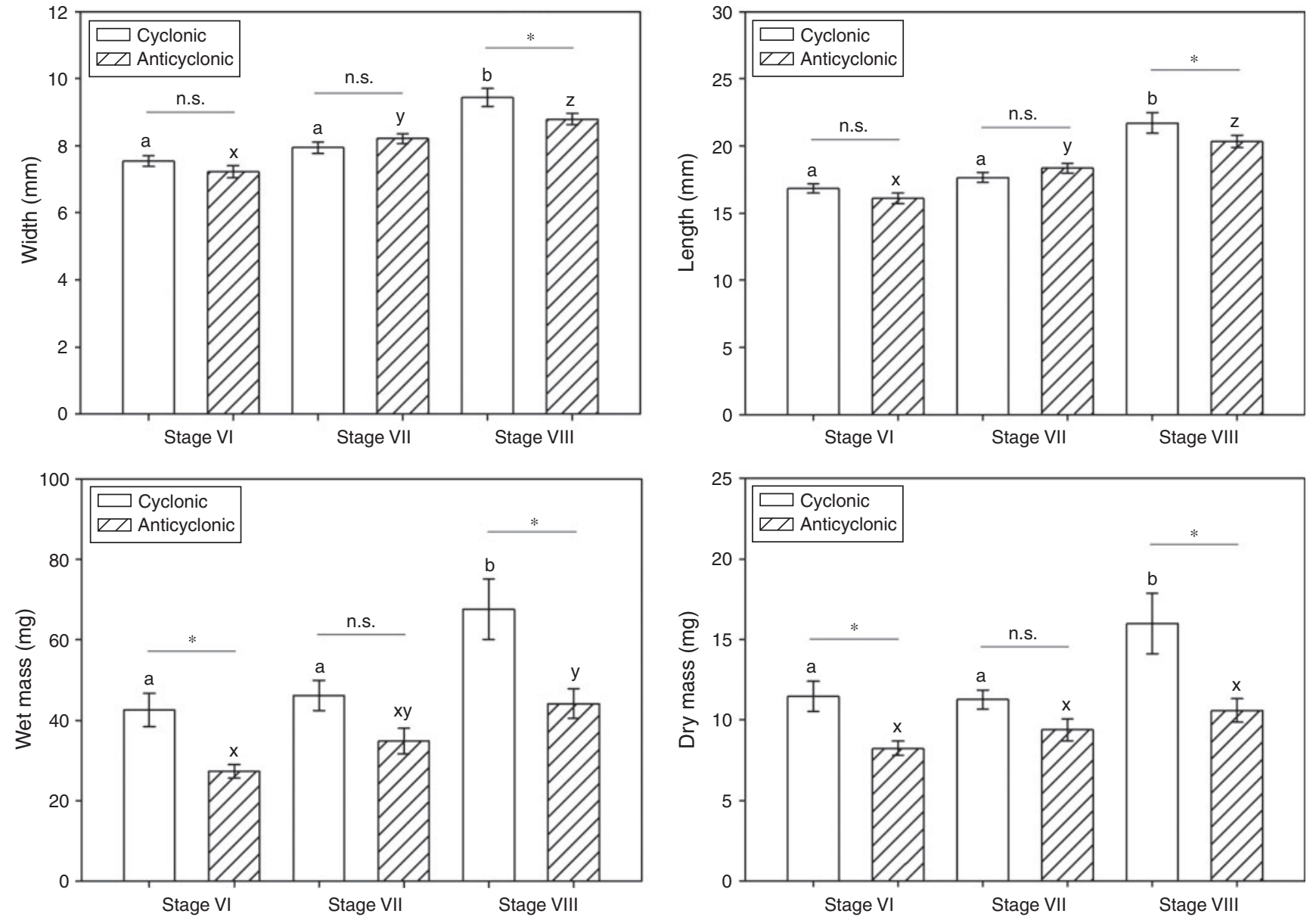

Fig. 2. Mean ( \pm s.e.) cephalic shield width, body length, body wet mass and dry mass for phyllosomas of Panulirus cygnus of three larval stages (VI, VII, VIII) sampled from cyclonic (CEs) and anticyclonic (AEs) eddies off Western Australia. Significant $(P<0.05)$ results of pairwise comparisons of means between CEs and AEs for each of the three larval stages are represented by as asterisk, with Bonferroni correction applied; n.s., non-significant. Significant $(P<0.05$, with Bonferroni correction applied) results of pairwise comparisons of means between each of the three larval stages within each of the two types of eddies are represented by those mean values not possessing an alphabetical letter in common. 

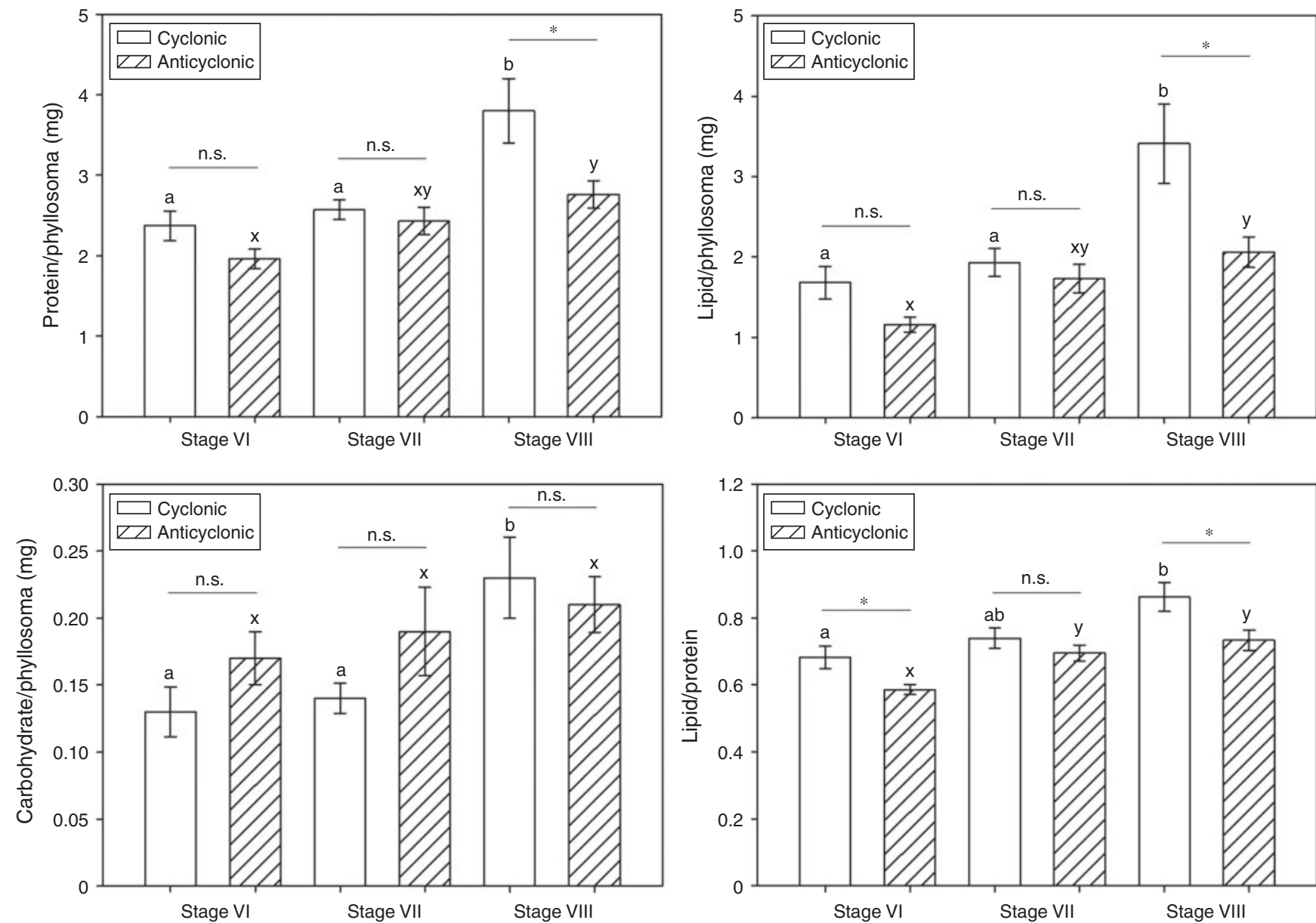

Fig. 3. Mean ( \pm s.e.) protein, lipid and carbohydrate amount (larvae $\left.{ }^{-1}\right)$, and lipid: protein ratio of phyllosomas of Panulirus cygnus of three larval stages (VI, VII, VIII) sampled from cyclonic (CEs) and anticyclonic (AEs) eddies off Western Australia. Significant $(P<0.05)$ results of pairwise comparisons of means between CEs and AEs for each of the three larval stages are represented by an asterisk, with Bonferroni correction applied; n.s., non-significant. Significant $(P<0.05)$ results of pairwise comparisons of means between each of the three larval stages within each of the two types of eddies are represented by those mean values not possessing an alphabetical letter in common.

The mean dry mass of phyllosomas from CEs was significantly higher than that from AEs for Stages VI and VIII $(P=0.006, P=0.001$; Fig. 2). There was a significant increase in the mean dry mass of phyllosomas from CEs from Stage VI to Stage VIII $(P=0.024)$, and from Stage VII to Stage VIII $(P=0.017)$.

\section{Phyllosomas from CEs v. AEs: proximate composition}

Comparisons of both mean lipid and protein contents per phyllosoma showed significant differences between CEs and AEs, and increases by larval stage, but not for the interaction term (2-way ANOVA, Table 4). The mean carbohydrate content per phyllosoma showed significant increases by stage, but there was no difference between CEs and AEs, or for the interaction term (2-way ANOVA, Table 4).

The mean lipid content per phyllosoma for CEs was significantly higher than that for AEs for Stage VIII $(P=0.005$; Fig. 3$)$. There was a significant increase of lipid content of phyllosoma from CEs from Stages VII to VIII $(P=0.004)$ and from Stages
VI to VIII $(P<0.001)$, and in AEs from Stages VI to VIII $(P=0.002$; Fig. 3).

The mean protein content per phyllosoma for CEs was significantly higher than that for AEs for Stage VIII $(P=0.008$; Fig. 3). There was a significant increase of protein content in phyllosoma from CEs from Stages VI to VIII $(P<0.001)$, and from Stages VII to VIII $(P=0.003)$, and in AEs from Stages VI to VIII $(P=0.006$; Fig. 3$)$.

For all of the analysed phyllosomas, regardless of location of capture, mean carbohydrate content (larva ${ }^{-1}$ ) of Stages VI, VII and VIII was respectively $0.15 \mathrm{mg} \pm 0.06,0.16 \mathrm{mg} \pm 0.08$ and $0.22 \mathrm{mg} \pm 0.08$ (Fig. 3). There was a significant increase of carbohydrate content for phyllosomas from CEs from Stages VI to VIII $(P=0.015)$, and from Stages VII to VIII $(P=0.015$; Fig. 3).

Phyllosomas from CEs v. AEs: lipid: protein ratio

Comparison of mean lipid: protein ratio showed significant differences for CEs $v$. AEs, and significant increases by stage, 


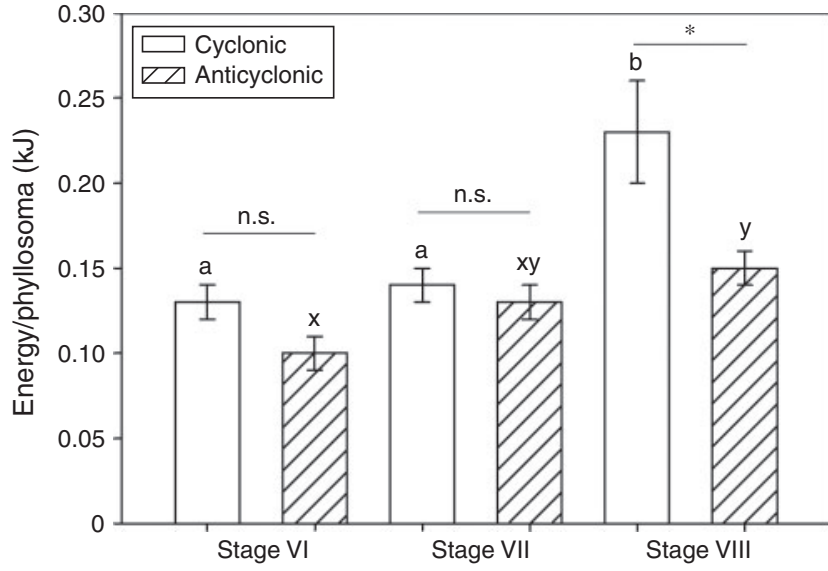

Fig. 4. Mean ( \pm s.e. $)$ total estimated energy content $\left(\right.$ larvae $\left.^{-1}\right)$ of phyllosomas of Panulirus cygnus of three developmental stages (VI, VII, VIII) sampled from cyclonic (CEs) and anticyclonic (AEs) eddies off Western Australia. Significant $(P<0.05)$ results of pairwise comparisons of means between CEs and AEs for each of the three larval stages are represented by an asterisk, with Bonferroni correction applied; n.s., non-significant. Significant $(P<0.05$, with Bonferroni correction applied) results of pairwise comparisons of means between each of the three larval stages within each of the two types of eddies are represented by those mean values not possessing an alphabetical letter in common.

but not for the interaction term (2-way ANOVA, Table 4). The lipid: protein ratio of phyllosomas from CEs was significantly higher than that of phyllosomas from AEs for Stage VI $(P=0.018)$ and Stage VIII $(P=0.009)$. There was a significant increase of lipid: protein ratio for phyllosomas from CEs from from Stages VI to VIII $(P<0.001)$, and from AEs from Stages VI to VIII $(P=0.001)$, and from Stages VI to VII $(P=0.012)$.

\section{Phyllosomas from CEs v. AEs: energy content}

Comparison of mean energy content per phyllosoma showed significant differences for CEs $v$. AEs, and significant increases by stage, but not for the interaction term (2-way ANOVA, Table 4). The estimated mean energy content of phyllosomas for CEs was significantly higher than that for AEs for Stage VIII $(P=0.005)$ (Fig. 4). There was a significant increase of energy content for phyllosomas from CEs from Stages VI to VIII $(P<0.001)$, and from Stages VII to VIII $(P=0.003)$, and for phyllosomas from AEs from Stages VI to VIII $(P=0.003)$.

\section{Discussion}

\section{Comparison between CEs or AEs replicates}

Within each of the three stages of phyllosoma analysed (i.e. Stages VI, VII and VIII), there was little or no difference in the morphometric measures or biochemical condition of larvae sampled from two CEs, or from two AEs. This strongly suggests that metabolism and feeding conditions for phyllosomas are similar between the two CEs, and between the two AEs, despite the considerable differences in their distance offshore and geographic separation from one another, that is, the centres of eddies being more than $150 \mathrm{~km}$ apart. Furthermore, the distances between these eddies indicate that they would have been formed at different times because counter-rotating mesoscale eddies meander westward after being formed along the margins of the shelf (Fang and Morrow 2003).

\section{Phyllosomas from CEs v. AEs}

Phyllosomas from CEs were consistently larger in wet and dry mass, and contained more protein, lipid and total energy on average than did those from AEs for all three larval stages. These results indicated that phyllosomas in CEs are in better nutritional condition than those in AEs, especially at Stage VIII when these differences had become substantial. In addition, the higher lipid: protein ratio of phyllosomas in CEs than in AEs could suggest that there is better food availability for phyllosomas in CEs than in AEs, because lipid is known to be catabolised at a greater rate than protein and carbohydrate during food deprivation of phyllosoma (Ritar et al. 2003). Furthermore, experimental feeding of $P$. cygnus phyllosomas of the same developmental stages as examined in this current study showed that lipid is rapidly accumulated when prey are readily available (Saunders et al. 2012). To the contrary, previous research has shown that the CEs of the Leeuwin Current generally exhibit oligotrophic oceanic conditions by global standards, whereas AEs have been classed as mesotrophic in nature (Waite et al. 2007a, Waite et al. 2007b). As a result, the AEs have consistently been found to be more biologically productive than are CEs, supporting significantly higher zooplankton biomass and more abundant mesozooplankton, which could be expected to provide much better feeding conditions for a generalist predator of zooplankton, such as phyllosomas. The study of the fatty acid profiles of phyllosomas from CEs and AEs suggested that the microbial food web operating in cyclonic eddies may provide better feeding conditions for lobster larvae, which could explain this apparent contradiction (Wang et al. 2014).

On average, there is substantially more lipid per larva for the phyllosomas from CEs than for those from AEs for stage VIII. These results suggest that CEs are likely to produce pueruli in a better nutritional condition in readiness to actively migrate across the continental shelf to settle and recruit on the coast (Jeffs et al. 1999). For example, the average of $1.4 \mathrm{mg}$ of additional lipid measured in Stage VIII phyllosomas from CEs $v$. AEs has the potential to support an estimated additional $35 \mathrm{~km}$ of cross-shelf migration for pueruli according to previous measures of energy consumption rate of $1.6 \mathrm{~J} \mathrm{~km}^{-1}$ (Phillips et al. 2006). Although this figure may vary if assistance is provided to pueruli by known shoreward-directed physical processes (Wilkin and Jeffs 2011). Regardless, the extent of the nutritional reserves available to the non-feeding pueruli of spiny lobsters appears to play a critical role in their successful completion of cross-shelf migration (Jeffs et al. 2001a, 2001b; Phillips et al. 2006; Fitzgibbon et al. 2013).

Besides nutrition, water temperature is the most important extrinsic factor in the regulation of larval growth of decapod crustaceans (Anger 1998). In some crustacean species, larvae tend to grow larger in colder $v$. warmer water, corresponding with Bergman's Rule (Shirley et al. 1987; Furota 1996). This is thought to be due to decreasing temperature resulting in enlarged cell size, slowed development and prolonged life span, all of which lead to an increase in maximum body size (Timofeev 2001). The higher mass of phyllosomas from CEs 
than from AEs in the current research may have been caused by the lower temperatures experienced in these cold-core CEs (Table 1). A previous study identified an inverse relationship between mean size of Stage VI phyllosomas of $P$. cygnus and the sea surface temperature at the location from which they were sampled (Ritz 1972). In addition, it has been found that at higher temperatures, overall feed consumption of cultured mid-stage phyllosomas decreased owing to reduced intermoult duration, resulting in reduced growth (Tong et al. 2000), and, consequently, the total larval duration has been found to decrease with increasing culture temperature (Matsuda and Yamakawa 1997). Furthermore, a distinct downward shift in the temperature optimum for the growth of late-stage phyllosomas has been reported in both $P$. japonicas and the packhorse spiny lobster, Sagmariasus verreauxi (Matsuda and Yamakawa 1997; Fitzgibbon and Battaglene 2012). At lower temperatures, phyllosomas had a lower metabolic rate but maintained their feed intake, providing for greater energy accumulation (Fitzgibbon and Battaglene 2012). The late-stage phyllosomas of $S$. verreauxi were shown to have a narrow temperature optima. Operating beyond the optima over the period of many weeks may lead to marked differences in their cumulative nutritional condition. Therefore, the cooler water temperatures in the CEs than in the AEs could be responsible for increasing the overall size and nutritional condition of phyllosomas at the same relative developmental stage.

Sea surface temperatures in the ocean region off the Western Australian coast have been warming at $\sim 0.1^{\circ} \mathrm{C}$ per decade since the 1950s (Pearce and Feng 2007). It is possible that the elevated water temperatures associated with climate change in this ocean region may be exceeding the temperature optima for the development of late-stage P. cygnus phyllosomas, and, in turn, contributing to a decline in larval nutritional condition and subsequent successful shoreward migration and settlement of pueruli (Pearce and Feng 2007; Poloczanska et al. 2007; Caputi et al. 2010). If so, constrained nutritional condition caused by the physiological effects of elevated water temperatures could be expected to be more pronounced among those larvae living in AEs, which have generally warmer water temperatures than those in CEs. This explanation is consistent with our observations of the consistent differences in nutritional condition of larvae between the two types of eddies, but remains to be empirically tested.

\section{Developmental stages}

The analyses of biochemical content in wild phyllosomas from Stage VI to VIII in the present study highlighted some key developmental changes in the nutritional content of larvae, especially in lipid, which was accumulated rapidly in larvae from Stages VI to VIII (Fig. 3). Lipid is used as the major energy store during larval development, probably because of its high energy density and buoyancy compared with protein and carbohydrate, which both yield approximately half the energy per unit of mass compared with lipid (Crisp 1976). High lipid concentrations of late-stage $P$. cygnus phyllosomas (Stage IX) (19.8-29.3\% DW; Limbourn and Nichols 2009), (7.0-22.4\% DW; Phillips et al. 2006), and of final-stage J. edwardsii phyllosomas (18.6-34.4\%; Jeffs et al. 2004) have been previously reported. Phyllosomas accumulate lipid as an energy store during their final developmental stages to power the nonfeeding post-larval or puerulus stage, which undertakes an energy-intensive migration across the continental shelf (Jeffs et al. 1999, 2001b, 2004). Significant increases of lipid content of phyllosomas of P. cygnus were found during development from Stage VI to Stage VIII for both CEs and AEs in this current study. This amounted to an average increase of $0.41 \mathrm{mg}( \pm 0.20)$ of lipid per larva $(33.9 \% \pm 14.6)$ from Stage VI to VII (Fig. 3), and an even larger accumulation of lipid from Stage VII to Stage VIII of $0.9 \mathrm{mg}( \pm 0.33)$ per larva $(48.4 \% \pm 17.5)$, on average, over all of the phyllosomas analysed.

In other species of spiny lobster, such as J. edwardsii, phyllosomas from mid-developmental stages (Stages VI and VII) are thought to be capable of tackling and consuming more active prey such as krill to provide for more rapid accumulation of lipid (Jeffs et al. 2004). There are also large increases in the activity of digestive enzymes from this stage, which could be related to an increase in food availability or prey-handling proficiency that precedes a large increase in phyllosoma size (Johnston et al. 2004). The results of the current study confirmed that there is pronounced lipid accumulation from Stage VI to VIII in phyllosomas of $P$. cygnus. This result suggests a possible change in diet in late-stage phyllosomas to prey with a high lipid yield, such as krill, as there is a narrow range of potential zooplankton prey in the wild with high lipid content (Saunders et al. 2012; Wang et al. 2013).

Overall, late-stage phyllosomas of $P$. cygnus in CEs of the Leeuwin Current are larger and in a substantially better nutritional condition than are those in AEs. These marked differences could be related to the ability of phyllosomas to accumulate nutritional reserves in higher water temperatures associated with AEs, and this needs further investigation. Reduced nutritional condition, especially lipid, of the subsequent post-larval (puerulus) stage has the potential to reduce the chances of successful migration, settlement and eventual recruitment into the coastal fishery for this lobster species. A similar process may also be in operation in other important species of spiny lobsters world-wide which have recently been shown to have declining post-larval settlements, and for which the nutritional condition of the post-larvae is also thought to play a key role in their successful settlement.

\section{Acknowledgements}

Phyllosomas for this study were collected from the RV Southern Surveyor provided by the Australian Marine National Facility under grant SS05-2010 (http://www.csiro.au/Organisation-Structure/National-Facilities/MarineNational-Facility.aspx, accessed 29 August 2011). The field research component of this project was funded by a grant from the Fisheries Research and Development Council of Australia (http://www.frdc.com.au/, accessed 2 April 2013) under FRDC Project Number: 2010/047. Satellite data were sourced from NOAA and analysed by the Integrated Marine Observing System which is supported by the Australian Government through the National Collaborative Research Infrastructure Strategy and the Super Science Initiative. This study was supported by the New Zealand China Doctoral Research Scholarship from the China Scholarship Council to M. Wang. This research is a contribution to the Worldwide Universities Network project; Ocean Eddies in a Changing Climate: Understanding the Impact of Coastal Climates and Fisheries Production. We thank all the people who assisted in sample collection and Brian Dobson for the help with the chemical analysis and his fine whistling accompaniment to the 
biochemical analyses. This research was conducted under ethics approval R2338/10 issued by Murdoch University and sampling of animals was permitted under Exemption-1921 issued by the Department of Fisheries Western Australia.

\section{References}

Anger, K. (1998). Patterns of growth and chemical composition in decapod crustacean larvae. Invertebrate Reproduction \& Development 33, 159-176. doi:10.1080/07924259.1998.9652629

Bligh, E. G., and Dyer, W. J. (1959). A rapid method of total lipid extraction and purification. Canadian Journal of Biochemistry and Physiology 37, 911-917. doi:10.1139/059-099

Braine, S. J., Phillips, B. F., and Rimmer, D. W. (1979). An illustrated key and notes on the phyllosoma stages of the western rock lobster, Panulirus cygnus George. Report 102, CSIRO Division of Fisheries and Oceanography, Division of Fisheries and Oceanography, Melbourne.

Brown, R. (2011). 'Governance of the Western Rock Lobster Fishery and Marine Stewardship Council Principle 3. Effective Management.' (Western Australian Department of Fisheries: Perth.)

Caputi, N., Chubb, C., and Pearce, A. (2001). Environmental effects on recruitment of the western rock lobster, Panulirus cygnus. Marine and Freshwater Research 52, 1167-1174. doi:10.1071/MF01180

Caputi, N., Melville-Smith, R., de Lestang, S., Pearce, A., and Feng, M. (2010). The effect of climate change on the western rock lobster (Panulirus cygnus) fishery of Western Australia. Canadian Journal of Fisheries and Aquatic Sciences 67, 85-96. doi:10.1139/F09-167

Chittleborough, R. G., and Thomas, L. R. (1969). Larval ecology of the Western Australian marine crayfish, with notes upon other panulirid larvae from the eastern Indian Ocean. Marine and Freshwater Research 20, 199-224. doi:10.1071/MF9690199

Church, J. A., Cresswell, G. R., and Stuart, G. J. (1989). The Leeuwin Current. In 'Poleward Flows Along Eastern Ocean Boundaries. Vol. 34'. (Eds S. J. Neshyba, C. N. K. Mooers, R. L. Smith and R. T. Barber.) pp. 230-254. (Springer: New York.)

Cresswell, G. R., and Griffin, D. A. (2004). The Leeuwin Current, eddies and sub-Antarctic waters off south-western Australia. Marine and Freshwater Research 55, 267-276. doi:10.1071/MF03115

Crisp, D. J. (1976). The role of the pelagic larva. In 'Perspectives in Experimental Biology and Zoology’. (Ed. P. S. Davies.) pp. 145-155. (Pergamon Press: New York.)

de Lestang, S., and Melville-Smith, R. (2006). West coast rock lobster managed fishery status report. Department of Fisheries, Perth, WA.

DuBois, M., Gilles, K. A., Hamilton, J. K., Rebers, P. A., and Smith, F. (1956). Colorimetric method for determination of sugars and related substances. Analytical Chemistry 28, 350-356. doi:10.1021/ AC60111A017

Ehrhardt, N. M., and Fitchett, M. D. (2010). Dependence of recruitment on parent stock of the spiny lobster, Panulirus argus, in Florida. Fisheries Oceanography 19, 434-447. doi:10.1111/J.1365-2419.2010.00555.X

Fang, F., and Morrow, R. (2003). Evolution, movement and decay of warmcore Leeuwin Current eddies. Deep-sea Research. II. Topical Studies in Oceanography 50, 2245-2261. doi:10.1016/S0967-0645(03)00055-9

Feng, M., Majewski, L. J., Fandry, C. B., and Waite, A. M. (2007). Characteristics of two counter-rotating eddies in the Leeuwin Current system off the Western Australian coast. Deep-sea Research. II. Topical Studies in Oceanography 54, 961-980. doi:10.1016/J.DSR2.2006. 11.022

Feng, M., Caputi, N., Penn, J., Slawinski, D., de Lestang, S., Weller, E., and Pearce, A. (2011). Ocean circulation, Stokes drift, and connectivity of western rock lobster (Panulirus cygnus) population. Canadian Journal of Fisheries and Aquatic Sciences 68, 1182-1196. doi:10.1139/ F2011-065
Fitzgibbon, Q. P., and Battaglene, S. C. (2012). Effect of water temperature on the development and energetics of early, mid and late-stage phyllosoma larvae of spiny lobster Sagmariasus verreauxi. Aquaculture 344349, 153-160. doi:10.1016/J.AQUACULTURE.2012.03.008

Fitzgibbon, Q. P., Jeffs, A. G., and Battaglene, S. C. (2013). The Achilles heel for spiny lobsters: the energetics of the non-feeding post-larval stage. Fish and Fisheries. doi:10.1111/FAF.12018

Furota, T. (1996). Life cycle studies on the introduced spider crab Pyromaia tuberculata (Lockington) (Brachyura: Majidae). I. Egg and larval stages. Journal of Crustacean Biology 16, 71-76. doi:10.2307/1548932

Gnaiger, E. (1983). Calculation of energetic and biochemical equivalents of respiratory oxygen consumption. In 'Polarographic Oxygen Sensors'. (Eds E. Gnaiger and H. Forstner.) pp. 337-345. (Springer: Berlin.)

Griffin, D. A., Wilkin, J. L., Chubb, C. F., Pearce, A. F., and Caputi, N. (2001). Ocean currents and the larval phase of Australian western rock lobster, Panulirus cygnus. Marine and Freshwater Research 52, 11871199. doi:10.1071/MF01181

Holm, S. (1979). A simple sequentially rejective multiple test procedure. Scandinavian Journal of Statistics 6, 65-70.

Jeffs, A. G., Willmott, M. E., and Wells, R. M. G. (1999). The use of energy stores in the puerulus of the spiny lobster Jasus edwardsii across the continental shelf of New Zealand. Comparative Biochemistry and Physiology. A. Molecular \& Integrative Physiology 123, 351-357. doi:10.1016/S1095-6433(99)00073-2

Jeffs, A. G., Chiswell, S. M., and Booth, J. D. (2001a). Distribution and condition of pueruli of the spiny lobster Jasus edwardsii offshore from north-east New Zealand. Marine and Freshwater Research 52, 12111216. doi:10.1071/MF01182

Jeffs, A. G., Chiswell, S. M., and Booth, J. D. (2001b). Spiny lobster puerulus condition in the Wairarapa Eddy off New Zealand. Marine and Freshwater Research 52, 1211-1216. doi:10.1071/MF01182

Jeffs, A. G., Nichols, P. D., Mooney, B. D., Phillips, K. L., and Phleger, C. F. (2004). Identifying potential prey of the pelagic larvae of the spiny lobster Jasus edwardsii using signature lipids. Comparative Biochemistry and Physiology. B. Biochemistry \& Molecular Biology 137, 487-507. doi: 10.1016/J.CBPC.2004.02.003

Johnston, D. J., Ritar, A. J., Thomas, C. W., and Jeffs, A. G. (2004). Digestive enzyme profiles of spiny lobster Jasus edwardsii phyllosoma larvae. Marine Ecology Progress Series 275, 219-230. doi:10.3354/ MEPS275219

Liddy, G. C., Phillips, B. F., and Maguire, G. B. (2004). Effects of temperature and food density on the survival and growth of early stage phyllosoma of the western rock lobster, Panulirus cygnus. Aquaculture 242, 207-215. doi:10.1016/J.AQUACULTURE.2004.05.034

Limbourn, A. J., and Nichols, P. D. (2009). Lipid, fatty acid and protein content of late larval to early juvenile stages of the western rock lobster, Panulirus cygnus. Comparative Biochemistry and Physiology. B. Biochemistry \& Molecular Biology 152, 292-298. doi:10.1016/J.CBPB. 2008.12.009

Linnane, A., Gardner, C., Hobday, D., Punt, A., McGarvey, R., Feenstra, J., Matthews, J., and Green, B. (2010). Evidence of large-scale spatial declines in recruitment patterns of southern rock lobster Jasus edwardsii, across south-eastern Australia. Fisheries Research 105, 163-171. doi:10.1016/J.FISHRES.2010.04.001

Matsuda, H., and Yamakawa, T. (1997). Effects of temperature on growth of the Japanese spiny lobster, Panulirus japonicus (V.Siebold) phyllosomas under laboratory conditions. Marine and Freshwater Research 48, 791-796. doi:10.1071/MF97148

Moore, T. S., Matear, R. J., Marra, J., and Clementson, L. (2007). Phytoplankton variability off the Western Australian coast: mesoscale eddies and their role in cross-shelf exchange. Deep-sea Research. II. Topical Studies in Oceanography 54, 943-960. doi:10.1016/J.DSR2.2007. 02.006 
Morgan, G. R., Phillips, B. F., and Joll, L. M. (1982). Stock and recruitment relationships in Panulirus cygnus, the commercial rock (spiny) lobster of Western Australia. Fishery Bulletin 80, 475-486.

Morrow, R., Fang, F., Fieux, M., and Molcard, R. (2003). Anatomy of three warm-core Leeuwin Current eddies. Deep-sea Research. II. Topical Studies in Oceanography 50, 2229-2243. doi:10.1016/S0967-0645(03) 00054-7

Paterson, H. L., Knott, B., and Waite, A. M. (2007). Microzooplankton community structure and grazing on phytoplankton, in an eddy pair in the Indian Ocean off Western Australia. Deep-sea Research. II. Topical Studies in Oceanography 54, 1076-1093. doi:10.1016/J.DSR2.2006. 12.011

Pearce, A., and Feng, M. (2007). Observations of warming on the Western Australian continental shelf. Marine and Freshwater Research $\mathbf{5 8}$ 914-920. doi:10.1071/MF07082

Pearce, A. F., and Phillips, B. F. (1988). ENSO events, the Leeuwin Current, and larval recruitment of the western rock lobster. ICES Journal of Marine Science 45, 13-21. doi:10.1093/ICESJMS/45.1.13

Phillips, B. F. (1986). Prediction of commercial catches of the western rock lobster Panulirus cygnus. Canadian Journal of Fisheries and Aquatic Sciences 43, 2126-2130. doi:10.1139/F86-261

Phillips, B. F., Brown, P. A., Rimmer, D. W., and Reid, D. D. (1979) Distribution and dispersal of the phyllosoma larvae of the western rock lobster, Panulirus cygnus, in the south-eastern Indian Ocean. Marine and Freshwater Research 30, 773-783. doi:10.1071/MF9790773

Phillips, B. F., Jeffs, A. G., Melville-Smith, R., Chubb, C. F., Nelson, M. M., and Nichols, P. D. (2006). Changes in lipid and fatty acid composition of late larval and puerulus stages of the spiny lobster (Panulirus cygnus) across the continental shelf of Western Australia. Comparative Biochemistry and Physiology. B. Biochemistry \& Molecular Biology 143 219-228. doi:10.1016/J.CBPB.2005.11.009

Poloczanska, E. S., Babcock, R. C., Butler, A., Hobday, A. J., HoeghGuldberg, O., Kunz, T. J., Matear, R., Milton, D., Okey, T. A., and Richardson, A. J. (2007). Climate change and Australian marine life. Oceanography and Marine Biology 45, 409-480.

Rennie, S. J., Pattiaratchi, C. P., and McCauley, R. D. (2007). Eddy formation through the interaction between the Leeuwin Current, Leeuwin Undercurrent and topography. Deep-sea Research.II. Topical Studies in Oceanography 54, 818-836. doi:10.1016/J.DSR2.2007.02.005

Ritar, A. J., Dunstan, G. A., Crear, B. J., and Brown, M. R. (2003). Biochemical composition during growth and starvation of early larval stages of cultured spiny lobster (Jasus edwardsii) phyllosoma. Comparative Biochemistry and Physiology. A. Molecular \& Integrative Physiology 136, 353-370. doi:10.1016/S1095-6433(03)00167-3

Ritz, D. A. (1972). Factors affecting the distribution of rock-lobster larvae (Panulirus longipes cygnus), with reference to variability of plankton-net catches. Marine Biology 13, 309-317. doi:10.1007/ BF00348078
Saunders, M. I., Thompson, P. A., Jeffs, A. G., Säwström, C., Sachlikidis, N., Beckley, L. E., and Waite, A. M. (2012). Fussy feeders: phyllosoma larvae of the western rocklobster (Panulirus cygnus) demonstrate prey preference. PLoS ONE 7, e36580. doi:10.1371/JOURNAL.PONE. 0036580

Säwström, C., Beckley, L. E., Saunders, M. I., Thompson, P. A., and Waite, A. M. (2014). The zooplankton prey field for rock lobster phyllosoma larvae in relation to oceanographic features of the southeastern Indian Ocean. Journal of Plankton Research. doi:10.1093/ PLANKT/FBU019

Shirley, S. M., Shirley, T. C., and Rice, S. D. (1987). Latitudinal variation in the Dungeness crab, Cancer magister: zoeal morphology explained by incubation temperature. Marine Biology 95, 371-376. doi:10.1007/ BF00409567

Strzelecki, J., Koslow, J. A., and Waite, A. (2007). Comparison of mesozooplankton communities from a pair of warm-and cold-core eddies off the coast of Western Australia. Deep-sea Research - II. Topical Studies in Oceanography 54, 1103-1112. doi:10.1016/J.DSR2. 2007.02.004

Timofeev, S. F. (2001). Bergmann's principle and deep-water gigantism in marine crustaceans. Biology Bulletin of the Russian Academy of Sciences 28, 646-650. doi:10.1023/A:1012336823275

Tong, L. J., Moss, G. A., Paewai, M. P., and Pickering, T. D. (2000). Effect of temperature and feeding rate on the growth and survival of early and mid-stage phyllosomas of the spiny lobster Jasus edwardsii. Marine and Freshwater Research 51, 235-241. doi:10.1071/MF99043

Waite, A. M., Muhling, B. A., Holl, C. M., Beckley, L. E., Montoya, J. P., Strzelecki, J., Thompson, P. A., and Pesant, S. (2007a). Food web structure in two counter-rotating eddies based on $\delta^{15} \mathrm{~N}$ and $\delta^{13} \mathrm{C}$ isotopic analyses. Deep-sea Research. II. Topical Studies in Oceanography 54, 1055-1075. doi:10.1016/J.DSR2.2006.12.010

Waite, A. M., Pesant, S., Griffin, D. A., Thompson, P. A., and Holl, C. M. (2007b). Oceanography, primary production and dissolved inorganic nitrogen uptake in two Leeuwin Current eddies. Deep-sea Research. II. Topical Studies in Oceanography 54, 981-1002. doi:10.1016/J.DSR2. 2007.03.001

Wang, M., O'Rorke, R., Nodder, S. D., and Jeffs, A. G. (2013). Nutritional composition of potential zooplankton prey of the spiny lobster phyllosoma (Jasus edwardsii). Marine and Freshwater Research 64, 1-13.

Wang, M., O’Rorke, R., Waite, A. M., Beckley, L. E., Thompson, P., and Jeffs, A. G. (2014). Fatty acid profiles of phyllosoma larvae of western rock lobster (Panulirus cygnus) in cyclonic and anticyclonic eddies of the Leeuwin Current off Western Australia. Progress in Oceanography 122, 153-162. doi:10.1016/J.POCEAN.2014.01.003

Wilkin, J. L., and Jeffs, A. G. (2011). Energetics of swimming to shore in the puerulus stage of a spiny lobster: can a postlarval lobster afford the cost of crossing the continental shelf? Limnology and Oceanography: Fluids and Environments 1, 163-175. 